\title{
A Comparative Analysis of Students' Achievement in Virtual Arts and Selected Instructional Strategies in Creative Arts in Nigeria
}

\author{
Aiyedun, Emmanuel Olugbenga* \\ Ogunlade, Olufunmilola** \\ Soetan, Aderonke***
}

\begin{abstract}
This experimental study compared the effectiveness of three instructional strategies for upper basic eight classes in Creative Arts in Nigeria. 674 participants were involved. Virtual Arts instructional strategy group consisted of 212 students; 198 for demonstration and 264 for the cooperative instructional strategies. Male and female participants were 315 and 359 respectively; while public and private schools had 389 and 285 participants. Pretest was administered on each of the groups before instructions were carried out according to the identified instructional strategies. Drawing and painting was the content area of Creative Arts subject employed; then the posttest to assess the effectiveness of the instructional strategies. The study revealed that all students improved achievement with each of the three instructional strategies, but Virtual Arts group showed most improvement, while demonstration group did more than the cooperative group. There was significant gender difference in the achievement of upper basic male and female students when taught using Virtual Arts, Demonstration and Cooperative strategies respectively. Virtual Arts, Demonstration and Cooperative strategies had significant main effect on upper basic students' achievement in Creative Arts in both public and private schools.
\end{abstract}

Keywords: Virtual arts, demonstration, cooperative, instructional strategy.

\footnotetext{
*Department of Fine/Applied Arts, Kogi State College of Education (Technical), Kabba, Nigeria

** Department of Educational Technology, University of Ilorin, Ilorin, Nigeria.

*** Department of Educational Technology, University of Ilorin, Ilorin, Nigeria.
} 


\section{Introduction}

The impact of educational technology in the teaching and learning of various disciplines in the present educational dispensation has been very encouraging. In keeping pace with modern educational environments, several instructional materials and resources have provided a center-point for research opportunities to seek some new or added means of effecting instructions in order to enhance both the teaching and learning strategies in most subject areas, which hitherto had not been available to teachers and students alike. The computer age seems to be bracing all odds to provide the means of surging forward and improving students' achievement in almost every phase of life, especially in the educational sector. By inference therefore, it is assumed that every discipline should be the better for it in the area of imparting knowledge. Despite the prevailing upsurge in the use of computer-assisted instructions in the educational world at large, its employment in Nigerian schools is still very minimal, but striving to have a place of note. Research efforts such as this could give added value to the employment of computer-assisted instructional strategies with upper basic teachers and students. Computer simulation has been described as computergenerated version of real-world objects and processes. Computer simulation can take many different forms, which could range from computer renderings of 3-dimensional geometric shapes to highly interactive computerized laboratory experiments, and games, among others (Idris, 2011). Virtual Reality is a technology that allows students to explore, control and manipulate computer-generated, 3-dimensional multimedia environment in real time. Classroom experience and literature inferences have proved to teachers that all students have different ways in which they learn. In any particular subject and at various times, a class of students is often at different levels. It therefore implies that the effective teacher that will reach all his students, and have them improve achievement in Creative Arts, must necessarily have to use different teaching strategies and also vary them from time to time, so as to meet the students' need (Smith, Bridge \& Clarke, 2002).

\section{Theoretical Framework}

This section relates to the philosophical basis on which the present work was based, with the intention to create a link between the theoretical aspects and the practical components of this research project. 
Crotty (1998) is of the opinion that the starting point of any research work must be to identify the methodologies and methods that are expected to be employed in order to justify the various choices made in the investigation and create a reliable foundation. This study is an experimental research to make a comparative analysis of students' achievement in virtual arts and selected instructional strategies in Creative arts in Nigeria. The research problem of the methodologies employed in identifying the differences in performance forms the basis from which the theoretical framework was adopted. Several instructional development models such as ARC, ASSURE, Dick and Carey, Organizational Elements Model, and Kemp Design Model, among others exist. Several of these instructional design models are based on previous ones. The basic model is generally referred to as ADDIE, an acronym meaning Analysis, Design, Development, Implementation and Evaluation (Clark, 2009).

Figure 1 shows the ADDIE model of instructional development cycle adapted from Spitzer (1991) that was employed in the present study.

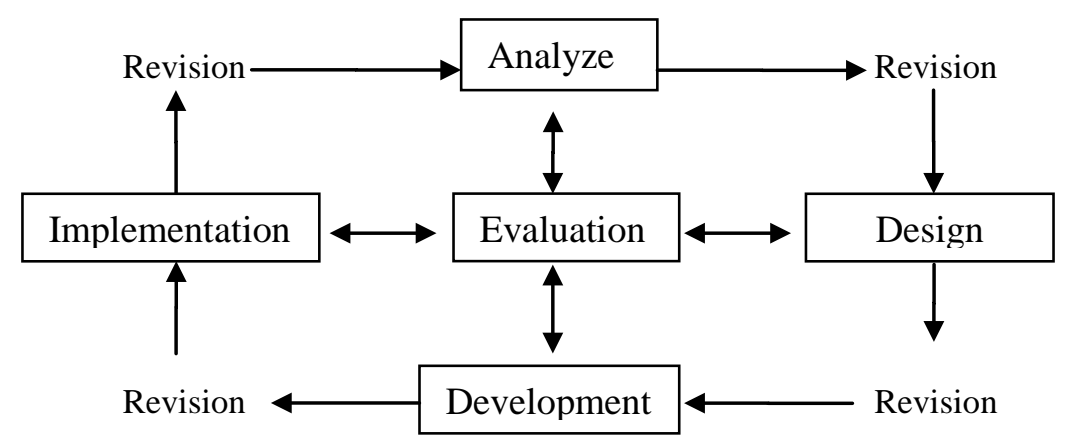

Figure 1: Model of instructional design cycle

Source:Spitzer, (1991).

Knowledge is constantly increasing (Anthony \&Egge, 2011). There are varying discoveries in educational circles on almost constant basis especially with the advent of computer-based activities. Indeed, the present dispensation is thriving on computer-based instructions and researches are multiplying in order to ascertain their varied effects on various disciplines (Onasanya, 2004). Presently, virtual reality is being employed in films, television shows and adverts, children instructional packages, computer games, and media relays of pictures. The 
employment of virtual art instructional strategy is still at its infancy in Nigeria although virtual gaming with varying displays in handsets is getting to be well known (Ayres \&Paas, 2008). It is to be verified if the employment of computer-based virtual arts instructional strategy will affect performance of Nigerian upper basic students in Creative arts either positively or negatively as compared with two selected instructional strategies, namely demonstration and group participation.

\section{Instructional strategies}

Bronwyn (2003) believes that a variety of teaching strategies, knowledge of student levels, and an implementation of which strategies are best for particular students can help teachers to know which teaching strategy will be most effective for their class in order for them to perform better. The first step to choosing an instructional strategy is to assess the students through tests from the textbook or curriculum being employed. Bronwyn (2003) listed several instructional strategies which the teacher could find useful such as direct instruction, inquiry-based learning, cooperative learning, and information processing strategies, among others. Olumorin (2000) is of the opinion that when appropriate instructional strategy is employed in carrying out practical art work, the dispensing and acquisition of the appropriate knowledge or skill are enhanced which by extension could positively affect students' achievement. The demonstration instructional strategy has to do with demonstrating by personal example how and what the students are expected to carry out in creative arts class. It is particularly suitable when it is employed for studies in painting, and designing.

Heather (2012) explains that the demonstration instructional strategy shows learners the modality in doing a task employing sequential instructions with the goal of having the learners to perform the task on their own. The procedure in using the demonstration instructional strategy in the classroom involves the teacher, or some other expert on the topic being taught, to perform the tasks so that the learner will eventually be able to carry out the same activity. The actual target is for learners to not only duplicate the acted task, but to recognize how he/she can problem-solve when unexpected obstacles or problem arise. 


\section{Statement of the Problem}

Despite the compulsory status of Creative Arts in Nigerian Secondary School, very few students in relation to other subjects often offer it. The table below shows attendance for five years in nine subject areas in Kogi State of Nigeria, and Creative Arts has consistently had the least attendance. Not only has the attendance been poor in comparison to other subjects, but the achievement has also been consistently poorer than other subject areas. This perennial problem of poor attendance and achievement by students in Creative Arts has been a concern to Creative Arts educators (Godwin, 2009).

Table 1

Kogi State Year 2002 - 2011 Upper Basic Certificate Examination Report

\begin{tabular}{lccccc}
\hline DESCRIPTION & 2002 & 2004 & 2007 & 2010 & 2011 \\
\hline ENG.LANGUAGE & 32,862 & 39,677 & 37,366 & 38,017 & 37,280 \\
MATHEMATICS & 32,850 & 39,677 & 37,336 & 38,017 & 37,280 \\
INT. SCIENCE & 32,636 & 39,677 & 37,336 & 38,017 & 37,280 \\
SOCIAL STUDIES & 32,796 & 39,677 & 37,336 & 38,017 & 37,280 \\
AGRIC. SCIENCE & 32,560 & 39,677 & 36,832 & 37,320 & 36,461 \\
BUSINESS STUDIES & 32,019 & 39,677 & 36,666 & 36,665 & 35,815 \\
HOME ECONS. & 11,901 & 14,226 & 15,040 & 16,977 & 17,305 \\
INTRO. TECH. & 28,633 & 34,294 & 32,343 & 32,025 & 31,945 \\
CREATIVE ARTS & 7,719 & 10,095 & 11,387 & 11,104 & 10.972 \\
PHYSICAL EDU. & 29,726 & 36,347 & 34,729 & 35,139 & 34,945 \\
\hline
\end{tabular}

Source:Kogi State Education Management Board 2002 -2011

Many reasons may be given for the poor attendance and achievement such as lack of teachers to teach the subject, the wrong notion among students in Nigeria that Creative Arts' skill is inherent and cannot be learned, and poor instructional strategies that could motivate students' interest, among others. Presently, there is a notable interest in the impact of Educational Technology phenomenon of virtual reality environments, of which experiments are still ongoing to ascertain what positive effects these computer-based simulations and environments could be if applied to specific areas and situations in classrooms and other social places. Arjen;\& Robert (2002) observed that through the past years, various authors have reported on the benefits of a virtual reality environment. The key argument is that a well-designed virtual reality 
environment can provide the sensation of presence and stimulates participation with objects in a scene. The emerging history of virtual reality in this dispensation is providing interesting avenue for researchers in various fields, such as library, schools, military, education and sports, among others (Char, 2009).

\section{Purpose of the Study}

The purpose of this experimental study was to make a comparative analysis of students' achievement in virtual arts and selected instructional strategies in Creative Arts, in Nigeria. The delineation of the specific purpose is reflected in the research questions and hypothesis.

\section{Research Questions}

This research sought answers to the following questions:

1: What is the general pattern of upper basic students' achievement in Creative Arts in both public and private schools when taught using Virtual Arts, Demonstration and Cooperative instructional strategies?

2: What is the achievement of upper basic male and female students in Creative Arts when taught using Virtual Arts, Demonstration and Cooperative instructional strategies in both public and private school?

3: Which of the instructional strategies (Virtual Arts, Demonstration and Cooperative) boosts upper basic students' achievement in Creative Arts in public and private schools?

4: What is the achievement of upper basic male and female students in Creative Arts when taught using Virtual Arts, Demonstration and Cooperative in public and private schools?

\section{Research Hypothesis}

The following hypotheses were tested in the study:

$\mathbf{H}_{\mathbf{0 1}}$ : There is no significant main effect of instructional strategies using Virtual Arts, Demonstration and Cooperative instructional strategies on upper basic students' achievement in Creative Arts in both public and private schools.

$\mathbf{H}_{\mathbf{0 2}}$ : There is no significant main effect of Gender on upper basic students' achievement in Creative Arts in both public and private schools when taught using Virtual Arts, Demonstration and Cooperative instructional strategies. 
$\mathbf{H}_{\mathbf{0 3}}$ : There is no significant difference in the achievement of Upper Basic students in Creative Arts when taught using Virtual Arts, Demonstration and Cooperative instructional strategies in public and private schools.

$\mathbf{H}_{\mathbf{0 4}}$ : There is no significant Gender difference in the achievement of Upper Basic students in Creative Arts when taught using Virtual Arts, Demonstration and Cooperative instructional strategies in public and private schools.

$\mathbf{H}_{05}$ : There is no significant difference in the achievement of male and female Upper Basic students in Creative Arts when taught using Virtual Arts instructional strategies in (i) public and (ii) private schools.

$\mathbf{H}_{\mathbf{0 6}}$ : There is no significant difference in the achievement of male and female Upper Basic students in Creative Arts when taught using Demonstration instructional strategies in (i) public and (ii) private schools.

$\mathbf{H}_{\mathbf{0 7}}$ : There is no significant difference in the achievement of male and female Upper Basic students in Creative Arts when taught using Cooperative instructional strategies in (i) public and (ii) private schools.

\section{Methodology}

This study was an experimental in nature. The between groups repeated measure design compared scores of participants on pretest and post-test to check differences due to treatment. To validate the instruments, test re-test method was used; Pearson product moment correlation coefficient yielded a reliability value of 0.94 . The students' learning content of the computer-based virtual arts instructional strategy for this study was limited to upper basic 8 Creative arts' topic of drawing and painting. The content requires that learners are given appropriate instructions and then get engaged in practical tasks of drawing and painting. The content has been selected for this study because drawing and painting has been noted as the center-point of Creative Arts engagements in the curriculum. Three, each of upper basic 8 public and private schools offering Creative Arts were engaged for this study, all restricted to the geographical scope of Kabba town, in Kogi State, Nigeria. A total of 674 respondents were involved, consisting of 389 public and 285 private school upper basic students. The male students accounted for 315 while their female counterparts were 359 in number. Intact upper basic 8 classes were involved, with six class teachers and their attendants assisting as instructors and helpers in the respective classes. Research samples were restricted to the researcher, instructional design experts and Creative arts teachers and the students of upper basic 8 
classes offering Creative Arts. The participants' scores were graded with scales of composition, proportion, perspective, balance and use of color.

\section{The Research Instruments}

The virtual instructional package was designed by computer experts in the University of Ilorin, Nigeria. A test re-test method was used for the reliability of the instruments at an interval of two weeks and Pearson Product Moment Correlation Co-efficient yielded a reliability value of 0.94 .

\section{Data Analysis Technique}

The data obtained were analyzed using descriptive statistics of frequency counts, mean and standard deviation to answer the research questions. ANOVA is the inferential statistics used to test Research hypotheses 1 and 2, while Research hypotheses 3 to 7 were tested using t-test each. These analyses were done with the aid of SPSS Version 19.

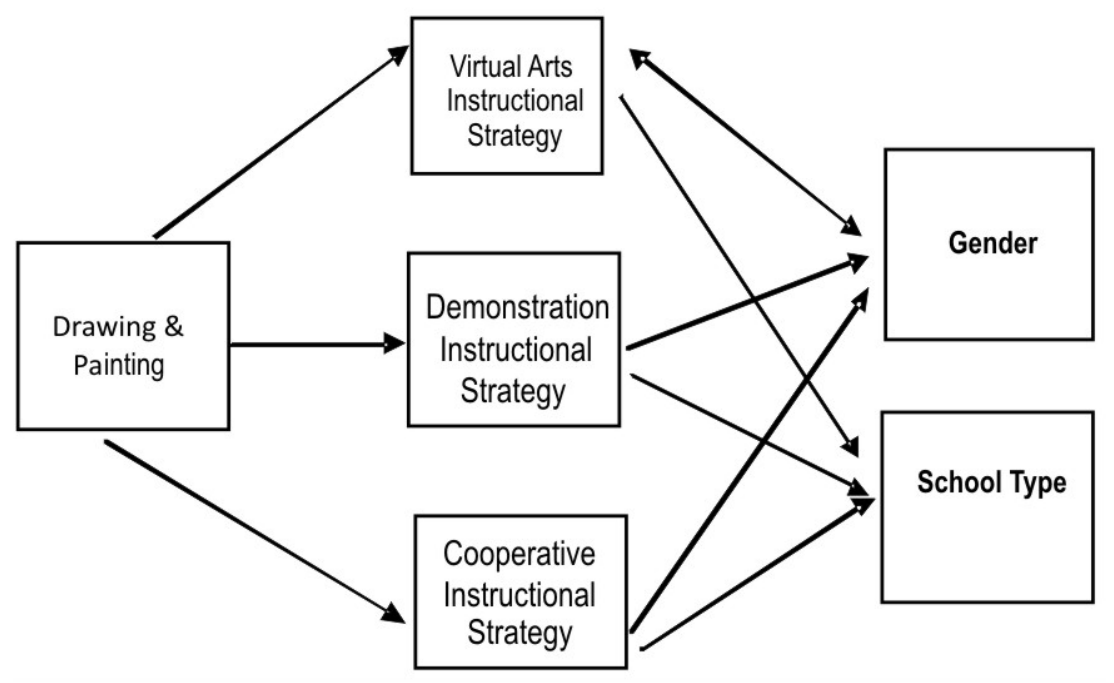

Figure 2.The figure of specification on the modality employed in the research 


\section{Results}

This section presents the analysis and interpretation of data collected for the study. Data obtained for this research questions were analyzed through their corresponding research hypotheses.

\section{Hypotheses Testing}

$\mathrm{H}_{01}$ : There is no significant main effect of instructional strategies (Virtual Arts, Demonstration and Cooperative) on upper basic students' performance in Creative Arts in both public and private schools.

Table 3

ANOVA Summary Table for Achievement Scores According to Instructional Strategies

\begin{tabular}{|c|c|c|c|c|c|c|}
\hline $\begin{array}{c}\text { Sources of } \\
\text { Variance }\end{array}$ & & $\begin{array}{l}\text { Sum of } \\
\text { Squares }\end{array}$ & df & $\begin{array}{l}\text { Mean } \\
\text { Square }\end{array}$ & $\mathrm{F}$ & $p$ \\
\hline \multirow[t]{5}{*}{ Strategies } & Between & 17.921 & 15 & 1.195 & 1.731 & $.041^{*}$ \\
\hline & Groups & & & & & \\
\hline & Within & 454.068 & 658 & .690 & & \\
\hline & Groups & & & & & \\
\hline & Total & 471.988 & 673 & & & \\
\hline \multirow[t]{5}{*}{ Gender } & Between & 4.800 & 15 & .320 & 1.292 & .201 \\
\hline & Groups & & & & & \\
\hline & Within & 162.915 & 658 & .248 & & \\
\hline & Groups & & & & & \\
\hline & Total & 162.715 & 673 & & & \\
\hline
\end{tabular}

Table 3 reveals that the instructional strategies (Virtual Arts, Demonstration and Cooperative) had significant main effect on upper basic students' achievement in Creative Arts in both public and private schools. The observed $\mathrm{F}$ value which is significant at the .05 level is indicated to be equal to $1.731 ; p<.05$. The hypothesis was thus rejected.

$\mathrm{H}_{02}$ : There is no significant main effect of Gender on upper basic students' achievement in Creative Arts in both public and private schools when taught using Virtual Arts, Demonstration and Cooperative instructional strategies.

It is further revealed in table 3 that Gender had no significant main effect on upper basic students' achievement in Creative Arts in both public and 
private schools due to instructional strategies employed. The observable F value is 1.292 at $p>.05$. The hypothesis was therefore not rejected.

$\mathrm{H}_{03}$ : There is no significant difference in the achievement of Upper Basic students in Creative Arts when taught using Virtual Arts, Demonstration and Cooperative instructional strategies in public and private schools.

Table 4

ANOVA Summary Table for achievement Scores Difference According to Instructional Strategies in Public and Private Schools

\begin{tabular}{clccccc}
\hline $\begin{array}{c}\text { Sources of } \\
\text { Variance }\end{array}$ & & $\begin{array}{c}\text { Sum of } \\
\text { Squares }\end{array}$ & df & $\begin{array}{c}\text { Mean } \\
\text { Square }\end{array}$ & F & $p$ \\
\hline Strategies & $\begin{array}{l}\text { Between } \\
\text { Groups }\end{array}$ & 224.149 & 45 & 4.981 & 12.622 & $.000^{*}$ \\
& Within & 247.840 & 628 & .395 & & \\
& Groups & & & & & \\
Gender & $\begin{array}{l}\text { Total } \\
\text { Between } \\
\text { Groups }\end{array}$ & 471.988 & 673 & & & \\
& Within & 144.043 & 45 & .512 & 2.223 & $.000^{*}$ \\
& $\begin{array}{l}\text { Groups } \\
\text { Total }\end{array}$ & 167.715 & 628 & .230 & & \\
\hline
\end{tabular}

*significance $p<.05$

It is shown in table 4 that there was a significant difference in the achievement of upper basic male and female students in Creative Arts when taught using Virtual Arts, Demonstration and Cooperative instructional strategies in both public and private schools $(F=12.622$ at $p<.5)$. The hypothesis was rejected as a result. The achievements mean score difference is 78.45 for Virtual Arts, 73.48 for Demonstration and 61.49 for Cooperative instructional strategies respectively.

$\mathrm{H}_{04}$ : There is no significant Gender difference in the achievement of Upper Basic students in Creative Arts when taught using Virtual Arts, Demonstration and Cooperative instructional strategies in public and private schools.

Table 4 also indicates the result of Gender difference in achievement. It shows that there was a significant gender difference in the achievement of upper basic male and female students' in Creative Arts when taught using Virtual Arts, Demonstration and Cooperative instructional strategies respectively. The hypothesis was rejected as a result. The difference in the mean scores of the upper basic male and female 
students' achievement in Creative Arts shows that the male and female students had 80.04 and 76.02 mean scores respectively in Virtual Arts group. In Demonstration group, both male and female students' had 73.68 and 73.25 mean scores while the mean scores in Cooperative were 59.00 and 62.58 for male and female upper basic students' respectively.

$\mathrm{H}_{05}$ : There is no significant difference in the achievement of male and female Upper Basic students in Creative Arts when taught using Virtual Arts instructional strategies in (i) public and (ii) private schools.

Table 5a

t-test Summary Table for Students' Achievement According to Gender in Public Schools in Virtual Arts Group

\begin{tabular}{clcccccc}
\hline School & Gender & $\mathrm{N}$ & Mean & SD & $\mathrm{df}$ & $\mathrm{t}$ & $p$ \\
\hline Public & Male & 98 & 79.90 & 7.12 & \multirow{2}{*}{152} & 126.22 & $.000^{*}$ \\
& Female & 55 & 73.56 & 6.74 & & & \\
\hline
\end{tabular}

*significance $p<.05$

The result on table 5 a shows that there was a significant difference in the achievement of upper basic male and female students' in Creative Arts when taught using Virtual Arts instructional strategy in public schools ( $\mathrm{t}$ $=126.238$ at $p<.05)$. The hypothesis was rejected. The mean score of male students $(\bar{X}=79.90$, SD 7.12) is greater than that of the female $(\bar{X}=$ 73.56, $\mathrm{SD}=6.74)$ in public schools.

Table 5b

t-test Summary Table for Students' Achievement According to Gender in Private Schools in Virtual Arts Group

\begin{tabular}{lllccccc}
\hline School & Gender & $\mathrm{N}$ & Mean & SD & $\mathrm{df}$ & $\mathrm{t}$ & $p$ \\
\hline Private & Male & 31 & 80.45 & 6.37 & 59 & -.152 & .879 \\
& Female & 29 & 80.69 & 5.73 & & & \\
\hline
\end{tabular}

*not significance $p>.05$

It is revealed from table 5b that there was no significant difference in the achievement of upper basic male and female students in Creative Arts when taught using Virtual Arts in Private schools $(t=-.152$ at $p>.05)$. The hypothesis was not rejected as a result. The mean scores for both 
male and female students as shown in table $5 \mathrm{~b}$ are 80.45 and 80.69 respectively.

$\mathrm{H}_{06}$ : There is no significant difference in the achievement of male and female Upper Basic students in Creative Arts when taught using Demonstration instructional strategies in (i) public and (ii) private schools.

Table 6a

t-test Summary Table for Students' Achievement According to Gender in Public Schools in Demonstration Group

\begin{tabular}{clllllll}
\hline School & Gender & N & Mean & SD & df & t & $p$ \\
\hline Public & Male & 85 & 73.79 & 6.92 & \multirow{2}{*}{153} & .223 & .824 \\
& Female & 69 & 73.54 & 7.00 & & & \\
\hline
\end{tabular}

*not significance $p>.05$

Table 6a shows that there was no significant difference in the achievement of upper basic male and female students in Creative Arts when taught using Demonstration instructional strategy in public schools $(\mathrm{t}=.223$ at $p>.05)$ in public schools. The hypothesis was thus not rejected. The mean scores for male and female students are 73.79 and 73.54 respectively.

Table 6b

t-test Summary Table for Students’ Achievement According to Gender in Private Schools in Demonstration Group

\begin{tabular}{llllllcc}
\hline School & Gender & $\mathrm{N}$ & Mean & SD & $\mathrm{df}$ & $\mathrm{t}$ & $p$ \\
\hline Private & Male & 22 & 73.27 & 6.86 & \multirow{2}{*}{44} & 66.779 & $.000^{*}$ \\
& Female & 23 & 72.39 & 7.86 & & & \\
\hline
\end{tabular}

*significance $p<.05$

Table 6b shows that there was a significant difference in the achievement of upper basic male and female students in Creative Arts when taught using Demonstration instruction strategy in private schools $(\mathrm{t}=66.779$ at $p<.05)$ in private schools. The hypothesis was therefore not rejected. The 
mean scores differ by 73.27 for male student to 73.39 for female students.

$\mathrm{H}_{07}$ : There is no significant difference in the achievement of male and female Upper Basic students in Creative Arts when taught using Cooperative instructional strategies in (i) public and (ii) private schools.

Table 7a t-test Summary Table for Students' Achievement According to Gender in Public Schools in Demonstration Group

\begin{tabular}{cllccccc}
\hline School & Gender & $\mathrm{N}$ & Mean & SD & $\mathrm{df}$ & $\mathrm{t}$ & $p$ \\
\hline Public & Male & 40 & 58.20 & 8.17 & 82 & 55.252 & $.000^{*}$ \\
& Female & 43 & 59.30 & 10.95 & & & \\
\hline
\end{tabular}

*significance $p<.05$

Table 7a reveals that there was a significant difference in the achievement of upper basic male and female students in Creative Arts when taught using Cooperative in public schools $(\mathrm{t}=55.252$ at $p<.05$ ) The hypothesis of no significant difference was therefore rejected. The difference in the mean scores reflects a 58.20 for male and 59.30 for female students respectively.

Table 7b t-test Summary Table for Students’ Achievement According to Gender in Private Schools in Demonstration Group

\begin{tabular}{clcccccc}
\hline School & Gender & $\mathrm{N}$ & Mean & SD & $\mathrm{df}$ & $\mathrm{t}$ & $p$ \\
\hline Private & Male & 40 & 59.80 & 10.78 & \multirow{2}{*}{179} & 81.572 & $.000^{*}$ \\
& Female & 140 & 63.70 & 10.08 & & & \\
\hline
\end{tabular}

*significance $p<.05$

Table 7b shows that there was a significant difference in the achievement of upper basic male and female students in Creative Arts when taught using Cooperative in private schools $(\mathrm{t}=81.572$ at $p<.05)$. The hypothesis was also rejected. The difference in the mean scores indicates that the male students had a 59.80 less than those of the female students with 63.70 . 


\section{Findings}

1. The achievement pattern shows a general improvement in posttest mean scores over the pretest mean scores in all the groups.

2. Virtual Arts enhanced students' achievement most in both public and private schools, followed by the Demonstration and least with Cooperative instructional strategy.

3. The upper basic male students achieved better than the upper basic female students using Virtual Arts; the male students achieved almost the same rate with the female students using Demonstration instructional strategy while Cooperative had the male students achieved lower than their female counterparts in Creative Arts in both public and private schools.

4. Virtual Arts instructional strategy boosted upper basic students' achievement in Creative Arts in public schools the most, followed by the Demonstration instructional strategy and least in Cooperative instructional strategy.

5. Virtual Arts instructional strategy fostered upper basic students' achievement in Creative Arts the most in private schools. The Demonstration instructional strategy was next and least with Cooperative instructional strategy.

6. Upper basic male students achieved better than the upper basic female students in Creative Arts when taught using Virtual Arts instructional strategy; there was almost equal level of achievement when taught using Demonstration instructional strategy and a close level of achievement when taught using Cooperative instructional strategy in public schools.

7. There was almost equal level of achievement of upper basic male students and upper basic female students in Creative Arts when taught using Virtual Arts instructional strategy; there was a little difference in their achievement using Demonstration instructional strategy, however, the male students achieved better than the female studentsusing Cooperative instructional strategy in private schools. 
8. Instructional strategies (Virtual Arts, Demonstration and Cooperative) had significant main effect on upper basic students' achievement in Creative Arts in both public and private schools.

9. Gender had no significant main effect on upper basic students' achievement in Creative Arts in both public and private schools due to instructional strategies employed.

10. There was a significant difference in the achievement of upper basic male and female students in Creative Arts when taught using Virtual Arts, Demonstration and Cooperative instructional strategies in both public and private schools.

11. There was a significant gender difference in the achievement of upper basic male and female students' in Creative Arts when taught using Virtual Arts, Demonstration and Cooperative instructional strategies respectively.

12. There was a significant difference in the achievement of upper basic male and female students' in Creative Arts when taught using Virtual Arts instructional strategy in public schools.

13. There was a significant difference in the achievement of upper basic male and female students' in Creative Arts when taught using Virtual Arts instructional strategy in private schools.

14. There was no significant difference in the achievement of upper basic male and female students in Creative Arts when taught using Demonstration instructional strategy in public schools.

15. There was a significant difference in the achievement of upper basic male and female students in Creative Arts when taught using Demonstration instruction strategy in private schools.

16. There was a significant difference in the achievement of upper basic male and female students in Creative Arts when taught using Cooperative instruction in public schools.

17. There was a significant difference in the achievement of upper basic male and female students in Creative Arts when taught using Cooperative in private 


\section{Conclusion}

Based on the findings of this study, the following implications can be drawn:

It can be inferred from the findings of the study that upper basic students' achievement in Creative arts in Nigeria would be greatly enhanced if the students are exposed to virtual arts instructional strategies. The acceptance and adoption of virtual arts instructional strategy could assist students in their individual learning and revision since the package should be available to them for such purposes. This is especially vital because Creative arts teachers are often in short supply and mostly inadequate in many schools where they are available. It could also encourage the students to take more interest and have more motivation for the learning of Creative arts. This study has contributed to knowledge in finding the effectiveness of virtual arts instructional strategy when applied on upper basic students' instructions in Creative arts. The use of virtual arts instructional strategy is therefore recommended for Creative arts teachers and students alike in learning of painting of upper basic public and private schools and for both male and female.

\section{Recommendations}

As a result of the findings and conclusions made in this study, the following recommendations were made:

1. Creative arts teachers should embrace virtual arts instructional strategy for Creative arts drawing and painting classes in upper basic schools.

2. Virtual arts packages could be developed for teachers and students usage.

3. Creative arts teachers should endeavour to develop students' competence in the use of technological applications like virtual arts that are intended for learning in one form or another.

4. Students could equally endeavour to explore the opportunities offered by computer-based virtual arts package, which could give the advantage of individual learning and revision.

5. Government and appropriate school authorities could equally embrace and support the use of virtual arts and environment.

6. The teachers need to be trained in the new computer-based innovation 


\section{References}

Anthony, C., \& Egger, A. (2011).The Nature of Scientific Knowledge.Vision learning, Vol. POS-3 (2).

Arjan, J. F; \& Robert, V. L. (2002). A Multimodal Virtual Reality Interface for 3D Interaction with VTK. Publication in knowledge and Information Systems, Department of Computer Science, Open University, The Netherlands.

Ayres, P., \& Paas, F. (2008). Learning from animations: A cognitive load approach. Manuscript submitted for publication.

Bronwyn,H. (2003). Classroom teaching methods. Retrieved May 17, 2016fromhttp://www.wisegeek.org/what-are-some-differentteaching-methods.

Char, D. (2009). Immersive Virtual Art \& the Essence of Spatiality. University of California Press, 2009.

Clark, B. (2009). The history of instructional design and technology.

Retrieved on 27, May 2016 from

http://www.slideshare.net/benton44/history-of-instructional-designand technology?from=embed

Crotty, M. (1998). The Foundations of Social Research: Meaning and Perspective in Research Process. London: Sage. Pp 56-78.

Godwin, O. I. (2009). The Implementation of Creative Arts Curriculum in Secondary Schools in Nigeria. An International MultiDisciplinary Journal, Ethiopia. Vol. 3 (3), April 2009. (Pp. 342358).

Heather, C. (2012). Culture, curriculum and change. Unpublished Ph.D. thesis, University of North Carolina, Chapel Hill. Retrieved on May 25, 2016 from http://www.learnnc.org/people/1227

Idris, B. (2011). Effects of computer simulation on the performance of senior secondary studentsin physics practical in Minna, Niger State. Unpublished B.Tech Project, Department of Science Education, Federal University of Technology, Minna, Nigeria.

Kogi State Education Management Board (2011). Kogi State Year 2011 Upper Basic Exams: Subject Analysis Report. 
Olumorin, C. O. (2000). An approach to practical art teaching. In A. I. Idowu., S. O. Daramola., S. A. Olorundare, N.Y.S. Ijaiya \& K. Lafinhan (Eds.) Guide to teaching practice (147-156), Ilorin: Haytee Press \& Publishing Company LTD.

Onasanya, (2004). Innovations in teaching and learning: computer in education. In I. O. Abimbola and A. O. Abolade (Eds.), Fundamental principles and practice of instruction. Ilorin: Department of Science Education, University of Ilorin.

Smith, N.G., Bridge, J., and Clarke, E. (2002). An Evaluation of Students' Performance Based on Their Preferred Learning Styles, in Pudlowski, Z.L., ed., Proceedings, 3rd Annual Conference of the UNESCO International Centre for Engineering Education, Melbourne, Australia: UICEE, 2002.

Spitzer, D. (1991). Introduction to instructional technology (2nd ed.). Boise, ID: Boise State University.

Received on: January 29, 2016

Revised on: May 31, 2016

Accepted on: June 01, 2016 